\title{
ECONOMY AND CULTURE. THE FRAMEWORK OF REFLECTION IN THE DEBATE ON THE COUNTRYSIDE
}

\begin{abstract}
This essay illustrates the tensions between the market economy and the democratic culture with reference to the situation wherein Polish villages faced the challenges of a new political and economic system after 1989. The author stresses the important role of assumptions derived from the theoretical basis of economics and sociology. She points to the "hidden role" that they play in the debate on the opportunities for rural communities to adapt to the requirements of modernity. The author challenges the view, quite widespread in sociology, according to which the rural community is insufficiently organized as a civic society, and that its situation is a result of a collision between the system of values governing traditional local cultural resources of agricultural villages and modern market rules. She demonstrates that democracy cannot be treated as an end in itself, but should be treated as a method of defence of civil rights and a guarantee of participation in public life. The author believes that villages [local communities] form an "indirect link" in which individuals come into contact with institutions of their society, and in which the principles of social coexistence are first developed on the basis of community ties. This leads to the conclusion that neither the territorial [local] basis nor the process of "growth" of local institutions. Linked in the long term with structures such as family, neighborhood, church, and nation, create an opposition to civic culture. History shows that successful countries have managed to reconcile the market
\end{abstract}

* Professor at the Institute of Rural and Agricultural Development; e-mail: m.wierusz@wp.pl 
economy with democratic principles. On the other hand, we can observe that the more the market economy dominates, the fewer family farms. It seems that the survival of family farms, and thus also the restoration of the cultural traditions of the Polish countryside, might require overcoming the "alienness of market and culture." The market, accompanied by the adjective "social", is therefore more appropriate for the implementation of the idea of democracy and meeting the expectations of sustainable development in the Polish countryside.

Keywords: economics, sociology, culture, democracy, development, community

\section{INTRODUCTION}

The central aim of this paper is to reflect on the relationship between two spheres - culture and the economy. I examine how the relations (including tensions) between the market economy and culture resonate and manifest themselves in the discourse on the countryside. The background for this problematic field will be the general horizon of development, but also the paradigm shift in science, especially in sociology and economics. The second, shorter time horizon, included in the analysis concerns the changes in the political and economic system in Poland after 1989. The central idea of the text is based the notion that the discussion on rural development in Poland is shaped by the tension between the spheres of the economy and culture. My goal is to examine these relationships as recognized by economists and sociologists, insofar as far as I am able to do that based on their statements. As author of the text, I am taking on the role of a "guide" of sorts, who tries to unravel the tensions, collisions and disputes that surround the eponymous formulation from the perspective of my field, which ethnology and cultural anthropology. I believe that contemporary anthropology has become a kind of art of holistic description. Having developed on the foundations of the old ethnography, anthropology has abandoned a simple inventory of cultural facts and turned towards an attempt to interpret the complicated plexus of trends and counter-trends of culture. Therefore, I am playing the role of an interpreter of various statements in the scientific discourse concerning the Polish countryside that I have encountered during the many years of my professional career. Adopting such a perspective liberates me from the rigor of a methodical and systematic presentation of specific views and positions of individual authors. Instead, I examine views which have emerged from the books I've read, papers I've heard presented, and disagreements that I have witnessed. I have had the opportunity to 
refer to them in my previous texts. They currently function as important anchor points for my own reflections. I count on the fact that trusting my own memory will make it easier for me to relate the characteristic rhetorical devices. It will help to evoke the style of some statements and to reproduce the atmosphere of discussion and the most characteristic lines of argument.

At this point it is worth emphasizing the specific approach to culture that characterizes anthropology as opposed to sociology. A sociologist focuses on the characteristics of individuals and investigates sets rather than systems. Anthropologists opt for a perspective allowing them to integrate related relationships. Thus, they are closer to a holistic approach to culture than to the proverbial "dismemberment of reality". Pointing out these differences already as the starting point will - I hope - help to lessen any impression of the "bizarreness" of this essay, which deviates from standard sociological text. My approach has advantages, which - in hindsight - provide a convenient instrument to describe the title issue, namely the inclusion of discrepancies and similarities between culture and the economy. I look at them through the prism of ways of describing and justifying them in the reflections on the countryside and agriculture. In other words, I am referring to the recognition by economists and sociologists of a kind of transition: from "alienness" to the gradual "taming" of culture and the economy as purviews of human activity. It is impossible to do this without a broader view of the issues associated with development and the way it is embodied in social thought. I acknowledge that the role of "guide" I have adopted in this text entails the risk of omissions, or the alleged lack of completeness. Nonetheless, I accept this challenge in the belief that the proposed form of reflection - with all the reservations - does indeed make sense.

\section{IN THE CIRCLE OF DISTINCTIVENESS, ALIENATION, AND SYNERGY}

Without going into detail, I will start with two terms: "distinctiveness" and "alienness", as they appear most frequently in the relations between culture and the economy. I would like to point out that they are not synonymous, hence I believe that their distinction is important. By its very nature, treating culture as an interrelated whole of mutually conditioned elements integrates human management (economics) into the same context of reality as that represented by tribal and peasant communities in many dimensions of their culture. In turn, adopting the historical perspective entails distinguishing between what concerns, on the one hand, the symbolic, spiritual sphere while and the other - the material, 
technical, and functional sphere associated with the civilizational dimension of development. The latter perspective reveals the truth that the trajectory of culture does not coincide with the development of economy on the axis of time. They form two distinct dynamics, which - applying the principles of geometry - can be illustrated as the difference between a helix and a straight line. I remember Alina Kapciak's metaphor of a musical fugue with a recurring melody in an ever-varying scale, used to illustrate a spiral-like dynamics of cultural change. It is a good comparison, because in the long run it reflects the permanence of human fate, the immutability of existential questions and the various answers to them in a space-time continuum. In contrast to the spiral, the ascending straight line, accumulating the achievements of the homo sapiens species, mainly in the material sphere (echoes of evolutionism), was said to reflect the development of human economy. Both lines - spiral and straight - point to their distinctness, and it is impossible to compare their trajectories, as they follow different paths over time. It is noteworthy that, for this reason, when researchers wish to recognize and describe them, they may - although not necessarily have to - be regarded as "alien." I would like to point out here that the inquiries concerning the foundations of human behaviour lead, on the one hand, to the search for universal laws, and on the other imply restraint in this regard. While the theory of economics, as well as the theoretical proposals of sociology, stem from claims to adjudicate on the universal premises of human behavior, in the perspective of culture the situation is different. The aforementioned straight line as an illustration of progress stimulated by tendencies of structural and functional differentiation based on "hard" indicators - refers to evolutionism. As is well known, it was from these premises that the concept of progress and modernization emerged as a necessary and directional process of change - from earlier to later, more perfect, stages. It is worth noting that, contrary to the approach described here, it appeared in Polish sociology relatively recently, as recently as only fifteen years ago, if we assume that Piotr Sztompka's book Socjologia. Analiza spoleczeństwa [Sociology Analysis of society] was the groundbreaking publication in that regard. [Sztompka 2002]. In fact, the critical development of the concept of "social becoming" was developed by the author in ten theses about modernization just three years ago [Sztompka 2013]. It is, in my opinion, too late for it to become a part of a broader scholarly circulation and shape the discourse about the countryside in Poland differently. The word "differently" means in a less aggressive and also less stereotypical way [Bukraba-Rylska 2008: 531]. Furthermore, it is too late to have any significant effect on the debate concerning the mutual relations between the market and culture. In the same way as sociological thought is always 
burdened by evolutionary assumptions, soo too is this happening in economics. Economic development - in line with these assumptions - is seen as a gradual accumulation of technological progress, which is supposed to provide improved living conditions for people.

Anthropologists perceive the development of economy and culture in a very different way from economists and sociologists. In view of the exploration of human cultures from different parts of the world, the premises of evolution and the general theory of social development, as evidenced in sociology and economics, cannot withstand criticism. Researchers of human cultures, without questioning the cultural universals, are primarily focused on the differences in cultures; their distinctness and specificity. They are more focused on describing differences than similarities. Such an optics also determines my own [self-ethnographic] way of looking at the countryside and agriculture. Following what I have said it is possible, to some extent, to explain why interest in anthropologically understood culture is at least limited, if not wholly absent, among economists and sociologists. The "alienation" attributed to cultural and economic relations, without blurring the real differences between them, is a symptom of the marked reluctance of economists to take cultural variables into account. ${ }^{1}$

They admit themselves that in their circle the notion of culture is unlikely to be used, based on the assumption (illusory, in my opinion) that identical results can be achieved irrespective of cultural realities [Kochanowicz 2010: 9]. The premises for such an assessment stem from the basics of classical and neoclassical economics. The use of the concept of homo oeconomicus as a universal economic entity annulled the necessity to deal with culture. The adoption of this model by economists, especially from the Chicago School, gave rise to, if not promised, an opportunity to construct a general theory of human behavior. The conviction that man is always guided by the maximization of his own benefits, that is, profit, utility and satisfaction derived from greed, was meant to be consistent with the attributes of reason and rationality [Wilkin 2016: 97, 227]. Let me digress at this point: from the perspective of contemporary research, especially one that seeks reasons for bringing market and culture closer together, the old certainties of classical economics have not proved as unequivocal as the optics of "Enlightenment" as a monolith would indicate. ${ }^{2}$

1 Jerzy Wilkin writes candidly that almost every economist knows that culture is important, but not everyone can explain how exactly this significance manifests itself [Wilkin 2016: 95].

2 What eighteenth-century thinkers expressed through the language of "self-love" or "selfish interest" did not correspond with the individualistic urge to meet only one's own needs. The two approaches differed as regards issues that are usualy the subject of people's concern, such as family 


\section{FROM THE PERSPECTIVE OF SYSTEMIC TRANSFORMATION}

The dispute over the meaning of both spheres - economics and culture - for economic development intensified in Poland during the post-1989 transformation. It was then that views emerged and started circulating that the countryside represented our chance, but that our agriculture was in poor condition. I would like to point out that in such a radically different assessment one could see the echo of a different treatment of socio-cultural issues as the domain of the countryside, and economic affairs as the domain of economics. At the same time the name "Ministry of Agriculture" was expanded with the phrase "and Rural Development." This could be interpreted as an attempt on the part of the ministry to go beyond the sectoral profile of agriculture and address the problems of countryside, too. It was the countryside that was supposed to be an asset in the process of systemic change. From today's perspective one can only try to guess what kinds of opportunities were foreseen at that time for the countryside. I do not feel that I am up to such task but I will say that, judging by the names of implemented projects, the commercial use of resources - including cultural ones - of the countryside dominated the activities. Returning to the aforementioned assessment: why was agriculture considered to be bad? The answer to that question is: for those reasons that referred to its major features as described and then copied in the economic literature, such as the unfavourable agrarian structure, fragmentation, which in the case of small individual farms was believed to be an obstacle hampering competition in the open international market. There was no reflection on the possibility of cooperating within that market, that is the complementarity of our agriculture, which could have been succesful, since that which had once been perceived as its weakness today is often seen as an asset. On the other hand, at that time, large state-owned farms [PGRs] proved mostly economically inefficient. As legacy of the former central planning system, they inherited its mismanagement. As a result of their transformation under the 1991 Act, half of them went bankrupt.

The absolutisation of market rules, introduced along with the systemic changes, polarized farmers. There was a growing group of farm households, as well as small households, which lived on social benefits. It was evidently adversely affecting the structure of the countryside, whose core had always been medium-size farms, and undermined the foundations of its management, rooted in the

and friends bound with shared responsibility. I have written more on this subject in a separate publication [Wieruszewska, 2012: 146]. 
tradition of Polish agriculture. Even the improvement of the economic situation of farmers associated with Poland's accession to the European Union and the activation of agricultural subsidies failed to turn around ther unfavourable processes in the Polish countryside and in agriculture. Krystyna Romaniszyn explains the inability to slow down the polarizing structural tendencies by citing the fact that the "protective umbrella" of the European Union came too late. It did not take place until 2004, i.e. a decade after modern, often international, agribusiness companies had managed to dominate the fields of supply, processing, and distribution in Polish agriculture. This deepened the discussed gap between the spheres of economy and culture.

Transformation began to be justified by the "intrinsic" principles of the capitalist order. Analyses of transformations of social consciousness at the beginning of the transformation era employed the phrase "pragmatization of consciousness." This term emphasized the change of people's orientation, towards shifting the accent to their material interests. It soon became clear, however, that the hasty diagnoses which announced the mass acceptance by the Poles of the pro-capitalist direction of change were not fully validated. They were dictated more by the enthusiasm of the reformers and their expectations of a quick fulfilment of their wishful thinking than a caution against the too high costs, especially for the Polish countryside and the agricultural segment. Soon, these costs were included in the price of survival of all that constitutes "the foundation of the Polish countryside" based on family-owned farms [Romaniszyn 2013: 86]. I do not recall the thought of Max Weber or Thorstein Veblen being referenced in the first stage of systemic changes, nor do I remember the views of the sociologist Jan Szczepański on the Polish countryside being taken into serious consideration. In my own experience as a researcher at the Institute of Rural and Agricultural Development of the Polish Academy of Sciences, I made the observation that that was incomprehensible to me at the time. Let me remind the reader that Jan Szczepański, co-author of the book on the renewal of the countryside, warned the reformers that they should not raise expectations above what was possible [Szczepański 1992]. In his counterargument against the bad press that peasants were receiving, he pointed out that they associated the nation with their territory. However, in my opinion, his views - the ones that were recorded and heard at institute seminars - fell on deaf ears. The same sentiment was evoked on various occasions by research into the countryside, which referred to the field experiences of my preceptor, Kazimiera Zawistowicz-Adamska, founder of the Łódź ethnographic school. Similarly, I did not see at that time any attempts to address the thoughts of Paweł Rybicki, not even his assertion that a truly strong bond is based on two pillars - community 
and organization. Arguments highlighting the significance of the identity of groups capable of defending not only their values, but also their interests, fell on deaf ears. Views that presaged the end of local communities corresponded to the promoted culture of individualism, cosmopolitan values considered typical of the fluid, "hybrid" reality of the global world. The deficit of historical and anthropological perspectives in rural studies, especially in the period of systemic transformation, led to a caricature bias in judging what actually happened in the countryside and in agriculture. In short, today I see more clearly that sociology and economics of the transitional era distanced themselves from the reality of the Polish countryside. Of course, this can be justified by the argument that "the views of sociologists and the message of their works was not quite used by Polish reformers and the new political elite" [Krzemiński, Raciborski 2007: 16]. This, however, does not diminish the weakness of the scholarly discipline, which failed in the face of the "great transformation," especially in the countryside and in agriculture.

\section{CONCERNING THE RHETORIC OF DE-AGRARIZATION}

Let me here cite the notion, one that is widespread in Polish sociology, proclaiming "the end of peasants," "de-agrarization," and the collapse of the isomorphism at three levels of reality: territory as a specific familiar place, the people who inhabit it, and the local and regional culture that is specific to them, recognizable as their own. Also popular were views criticizing the farmers' attitude of "entitlement", their parochialism, lack of understanding of market rules, poor civic competence, and anachronistic mentality. Even now, a popular and influential daily writes about the "archaic social structure" of Poland, which results from the fact that the Polish have " $40 \%$ of the rural population, unmatched in developed countries." According to the author of this assertion, the Poles are encumbered by a "mental and civilizational backwardness" and "archaic agrarian relations," which must [emphasis by the author] disappear, and "Polish modernization must be expressed in its essential part through urbanization [...] [Majcherek 2016: 9]. In the text devoted to the relationships between the countryside and the city, which I have described from the perspective of the opposition, antagonism, and tangled narratives, I have referred to this particular example as part of the broader phenomenon of the "bad press" given the countryside. I have expressed the hope that the quoted view of the journalist was not the last word dissolving the knot of tangled narratives devoted to the countryside [Wieruszewska 2016: 67].

The milieu of economists and sociologists misunderstood the issue that undermined - through the anthropological narrative - the penchant for a "jumbled" 
look at the countryside and agriculture. The latter, contrary to the teachings of Władysław Grabski, ignored sociological content because it showed the phenomena of collective life inherent for the countryside, because it touched upon the imponderables that were the actually bonds of the countryside. As a result of focusing on the practical aspect, represented by experts and advisors, in sociology and economics of the transition period, the statistical computations, percentages, and presentations of numerical data failed to take into account the longue durée, that is, all that makes agriculture and rural reality permanent components of civilization [Wieruszewska 1991]. The period of transformation after 1989 was, in its own way, a time of profound change, therefore by its very nature it can be compared to another "ground-breaking moment" in the life of the Polish countryside. I am thinking here of 1936, when a resolution was adopted to establish the Institute of Rural Culture.

\section{THE LIVING INSPIRATION - ACHIEVEMENTS FROM 1918-1939}

The regaining of independence by the Polish state after 123 years of partition created a climate of nationwide mobilization, in which the countryside and peasant society had an indispensable role to play as the largest social group, whose mission was to defend and sustain the existence of the nation. In the era of the Second Polish Republic (1918-1939), views different from those of the sociologist-socialist and evolutionist Ludwik Krzywicki were not only heard but also appreciated in public life. This is evidenced, for example, by the fact that Władysław Grabski, an adversary of Ludwik Krzywicki and the first president of the scientific council of the aforementioned Institute, was able to create a system of sociology of the countryside and apply it in his didactic work as the first Rector of the Warsaw's School of Life Sciences (Szkoła Główna Gospodarstwa Wiejskiego, SGGW). It was Grabski who emphasized how special the time was, when rural youth, unlike in the past, wanted to "have their own face" and believed in the countryside and the possibilities for its development on its own terms. [Wieruszewska 2008: 31]. Despite the traumas of the war and unfavourable conditions after its end, Władysław Grabski's achievements in the field of rural sociology formed the basis of an original, independent thinking, against the pressure of those ideologists who, according to his own assessment, had no idea what the countryside and agriculture was all about. The measure of these defects was the separation of economic and socio-cultural issues in the approach to the countryside. Another scholar of peasant pedigree - Jędrzej Cierniak, curator of out-of-school education, the son of the Zaborów Land, appealed to give the countryside a chance 
to be itself, which corresponded with the tone of discussion set by the father of sociology of the countryside, Władysław Grabski. Today, such intellectual inspirations should be considered as part of the current problems of identity, as being on the one hand an element of cultural differentiation, and on the other an accurate recognition of oneself among others [Wieruszewska 2008: 42]. It is difficult to understand, however, why these and similar views voiced in the era of the Second Polish Republic are so marginalized, considered as unimportant if not anachronistic, especially when pluralism is so celebrated. One such opinion was voiced by Helena Radlinska, who in her work as social pedagogue emphasized the positive meaning of the sense of distinctiveness of the countryside - not separatism, isolationism, or parochialism, but a specific distinctiveness. I am not convinced by the argument that the paradigm of "constructing the social world" [Krzemiński, Raciborski 2007: 15] developed in the field of sociology, which allegedly explains, even today, the disregard for the remnants of the pre-modern world in social studies, the remnants which - to some extent - were engrained in the reality of the Polish countryside and agriculture. Another objectionable issue is the fact that this cognitive nonchalance is combined with a banal, and not easily acceptable argument; namely that this problem does not fit within the model of "top-down modernization." Actually, the latter was only attributed to the transformation some years later [Kościański 2016]. Thus, at the beginning of the systemic challenges, views bordered on political pluralism were considered unnecessary, and rejected out of hand. Their stigmatization as a "ballast" of transformation and the proverbial "ball and chain on reform" entered into the politically correct narrative. Twenty-six years after the Round Table talks and the June 1989 election in Poland, Artur Kościański interprets this process as "a planned strategy to cut off the political and active role of citizens in the social system and in the space between family, markets and power" [Kościański 2016: 245]. This may look like an historical irony, especially given that concepts coined by sociologists to describe the rural world, such as "depeasantization" or "defamilization," along with the "dirty" - that is local, familiar social capital - in my opinion proved too far-fetched in the view of the rural realities. Current manifestations of a "quasi-return" to the features and structures that the winds of history and modern tendencies allegedly swiped away from the stage of history (to use Ludwik Krzywicki's phrase) call for a deeper reflection. Against the backdrop of the belief, widespread in the economic literature, that family farms are bound to disappear as a result of allegedly universal and irreversible rules, it is not easy for arguments advocating their protection and sustenance to be heard and acknowledged. [Wieruszewska 1992, 1996: 293, 2000: 539, 2008: 31, 2014: 139]. 
Therefore, a valid question arises: Do the mainstream views really have any serious arguments aside from their attachment to "universal and irreversible rules"? I do not see any, nor any reasons supporting them, be they economic, social, ecological, or cultural reasons. Voices that proclaim the inevitable disappearance of family farms are, apart from their doctrinal embeddedness in the already worn-out paradigms, devoid of merit. One can still ask whether the finale, the end - not just the end of history (Francis Fukuyama, author of that notion, later retracted it) but also other deterministic assumptions that sociological theories were wont to promote in reference to local rural communities, family agriculture, as well as the countryside as a place and territory in space - have proven to be premature? This is especially true when considering the concept of sustainable development. Today, Władysław Grabski’s concept that the negative qualities of capitalism, especially morally, can be reduced, and in a sense, removed, by references to culture is worth reconsidering more than ever before. This is the first important tangential point I see in the reflection on the relationship between the two spheres: culture and the economy.

\section{THE LINGUISTIC ASPECT OF THE DEBATE}

Today, when the state of economy can be described as "turbocapitalism" and "McWorld" [Romaniszyn 2013: 61], the ostensibly oxymoronic phrase "oppressive freedom" takes on a completely new meaning. The term is perfectly fitting to describe the appeals made to farmers since 1989 urging them to embrace entrepreneurship and independent market play, to "take matters into their own hands" instead of seeking state aid. It must be added that this has been done in parallel with disguising the fact that in an agriculture ruled by the market there is no place for peasant farms. [Romaniszyn 2013: 78]. As paradoxical as it sounds, the thesis of the development of agriculture through the fall of agriculture, or the development of the countryside through the disappearance of family farms, has been encapsulated in a "newspeak" since the time of transformation. On one hand, it is the outcome of previously used antinomies such as "truth - lie," "independence of thought - subordination to official ideology," "conscience as the centre of control - discipline as extortion," "civil courage versus fear," "solidarity of equal citizens versus hierarchy," "pluralism - uniformity," to name just a few. Democratic values attributed to one element of the antinomy were contrasted with that which allegedly undermined (through the use of the devastating phrase homo sovieticus) the socio-cultural structure of the countryside as a community. 
In the sociologists' capacity as experts and advisers, their liberal thought rejected any reflections derived from communist criticism. It was only in 2004 that a book was published that approached 'community' seriously, and made it possible to revive the contemporary political and philosophical debate. [Gawkowska 2004: 163]. One should note the distinctive character of language used to describe the social reality of transformational era. It is understandable that a living language accepts new words, while dropping others. Usually, words whose designates disappear become obsolete. I would like to note, however, that with regards to the Polish countryside, I have not found enough justification for the use of the term "rural areas," or for the very frequent appellation "entitled" in reference to the attitude of farmers, or to the processes of "depeasantization" and "defamilization". Similar linguistic manipulations have also replaced the category of "common good" in reflection on public interest. Terms such as restructuring, multifunctionality, entrepreneurship, began to mark the azimuth of the desired direction of change. Adaptation to the market economy, democratic principles, and the rule of law has set the main goals and vision for development. More detailed strategies, as the basis for decision-making, have been delegated to the local governments. Their governing principle was to be the principle of subsidiarity, implemented "from the bottom" in accordance with the grass-roots movement philosophy. It could be expected that such an approach would result in greater empowerment of the countryside and expand the activity of non-governmental organizations outside the municipality structures. That, however, has not happened. This situation aptly reflects the title of the chapter "The countryside - solectwo [village council]; farmers, or unwanted social capital?" [Wieruszewska 2011: 55]. In my conclusion then I stated that the lack of cultural grounds for an agreement that is supposed to generate trust - crucial for cooperation - undermines the basis of self-organization. Thus, the question arose whether the local action groups recognized the axio-normative basis for the renewal of the common good? The so-called Local Action Groups under the Leader Program, which brought together several neighbouring municipalities and several dozen villages, have in fact failed to foster communication. Instead, they have hindered the involvement of the rural population in the immediate area of their everyday lives. This lack of sensitivity to the rural context in the Leader Program is mirrored in Polish education, as evidenced by a comparison of Polish and English geography textbooks. The vastly different approach to teaching geography in Poland and the United Kingdom has a bearing on their attitude towards the countryside and is a derivative of different theoretical and methodological models. While Polish textbooks continue to be 
dominated by the concept of urbanization of space, English textbooks focus on specific problems, not figures. Students are encouraged to interpret everyday life situations. This clearly communicates the objective to teach students to identify and name problems they might encounter in their own life, rather than merely estimate the percentage of indicators. In English textbooks, space is treated not as an "area" but as a "place" with unique natural and social features. Such space is experienced by people and interpreted in various ways. The lack of such an approach, despite examples of reorientation of research, continues to occur in the economic-geographical approach to rural space in Poland. This is due to a kind of "cognitive insulation" against the cultural context, which is noticeable in the disciplines dealing with the countryside and agriculture, hence the lack of reflection on popular terms adopted together with the "newspeak." As I have mentioned, the phrase "rural areas" has become popular in Polish writings about the countryside (the Polish term obszary wiejskie is a calque of the original). I emphasize "areas" - and not territories or places - as spaces "tamed" by people. The wording "rural areas" has been used as a colloquial phrase, as seen in official documents, titles of books, and scientific papers. At the same time it has spread - in my opinion beyond measure - incorrectly replacing other concepts and excluding them from the field of reflection, such as the countryside, space, or territory. This would not be a complaint if there were arguments more serious than merely a convenient turn of phrase and superficial rhetoric. It is important that the term "countryside" still has its designates in reality. It is worth reminding ourselves that the direct spatial contact, typical of the village as a small settlement group, began to be appreciated again in the implementation of countryside restoration projects. This is because they reinforced the identity and communal life of rural communities. Projects which were addressed with increasing frequency to the village councils (solectwo) and not - as before - exclusively to municipalities as the seat of the former administration and now local government, are a good illustration of the will to oppose the simplified theses of sociologists alleging that the countryside is "uncivic." Recognition of the specific character of the informal networks of cooperation that are strongly rooted in rural traditions undermines the claims that the countryside has withdrawn from social life. All of this restores the prerequisite to take into account the cultural context, not only as regards the model of democracy but also as the basis of various market economies. [Gumuła 2000: 117]. 


\section{CULTURE - MARKET - ENTANGLED NARRATIVES}

I well recall the hopes expressed by Jerzy Woś on the threshold of the transformation that the development of the market system would take into account our culture - Polish experiences and identity [Woś 2000: 570]. Support for the social market economy, which was postulated in the opening speech made in the Parliament by Tadeusz Mazowiecki, the first Prime Minister of the Third Republic of Poland, came the closest to fulfilling those hopes. Article 20 of the Constitution of the Republic of Poland also specifically mentions it. It may seem odd that the considerable support for this model at the beginning of the transformation period was interpreted as a positive reaction to the adjective "social," without however any judgment as to whether such a principle would become a reality in Poland [Swadźba 2000: 500]. This brings to mind the success of the social market economy introduced in Germany after World War II. The ideas of German ordo-liberalism have proven to be a successful combination of the role of the state and the principles of democracy and free competition - precisely by referring to culture. If we accept that culture is a cult of values, we will better understand that the recognition of values such as responsibility and freedom at the same time provided the basis for a social market economy in German society after World War II.

The "alienation of the economy and culture" visible today is further deepened by the new dimension of unfavourable phenomena. The facts that the market is alienated from culture and management from society, that the so-called money culture is fuelling wastefulness, that the market is dominated by the cult of quantity rather than quality, raise serious questions. Is culture going to surrender to the market? Will the market overwhelm culture? These questions, and the phenomena that led to them (due the lack of space I am not able to go into any detail here), are no longer so easily silenced by arguments that "the problems are going to solve themselves on their own", as was postulated at the beginning of the transformation. It was well known that success was achieved by those countries that succeeded in reconciling the principles of democracy and the free market. There was no doubt about the accuracy of the assertion that "capitalism has proven to be the most adaptable, capacious and efficient system of all that we know from history." [Wilkin 2016: 136]. It was not until much later that an undertone of contestation, or at least a deeper reflection, emerged. With it, new formulations were introduced into the discourse, which characterized the time of "great change" as "top-down modernization" and "top democratization" of the Polish society [Kościański 2016: 234, 249]. By the way, features of top-down 
modernization appeared in Polish agriculture as early as the 1970s in the framework of the socialist economy [Filipkowski 2016: 162].

It would be wrong, however, to interpret the fact that, unlike in other states of the socialist bloc, in Polish agriculture individual property as the mainstay of capitalism. ${ }^{3}$ I myself have had such expectations, even though I remembered the words of Władysław Grabski about "squaring the circle" on the path of Polish agriculture to capitalism. I would like to remind readers that such a pioneering accomplishment as the creation of the system of 'sociology of the countryside' required a thorough diagnosis of the state of research on the countryside in other countries - France, Germany, and the United States. This diagnosis revealed gaps in the research fields of foreign authors, including Russian and English, in the sense of omitting, underestimating, and even misunderstanding of issues that Grabski believed were deserving of examination in the sociology of the countryside. He pointed out the wrong directions in the research; firstly because it was based on a false hypothesis of unidirectional development, and secondly because it did not concern the countryside "as such." Many years later, Bogusław Gałeski addressed the same issue of the desertion of disciplines from the most important field of problem sociology. He drew attention to the incommensurability that exists between the knowledge of phenomena observed in rural communities and the knowledge of what such community is, what bonds constitute it and what transformations they are experiencing. I recall a conclusion inspired by my conversation with Prof. Zbigniew T. Wierzbicki ${ }^{4}$ many years ago. We both agreed that the countryside we knew from Central and Eastern Europe and, broadly speaking, the whole Slavic area, did not exist in the West. It was possible to talk about farms, agriculture, rural environs, even rural areas while ignoring the fact that the real sociological problem in the countryside concerns the interpersonal aspect [emphasis by the author], meaning the things that bring people closer or farther away from one another. In order to understand what, according to Grabski, constitutes the countryside as a living space and a field for analysis, one would need to go back to the pre-World War II era. I leave aside

3 The model farms promoted by the socialist state as exemplary ,fattening farms”, ,extra quality class" were not so much free market niches in non-market economy, but rather a kind of symbiosis between peasant resourcefulness and the agricultural policy of the state. These are manifestations of a top-down modernization policy towards rural areas in the 1970s in Poland [Filipkowski 2016:162].

4 I am writing these words on the day of Professor Wierzbicki's funeral in Warsaw's Powazki cemetery, paying homage to Him as a scholar and educator of young sociologists of the countryside in Poland [20 June 2017]. 
the sad reality that the period following the Second World War, in the era of real socialism, did not offer any opportunity to develop these ideas in Poland. It is well-known that the arguments of the opponents of Grabski won; fascinated with the modern tendencies of socialization of agriculture and mainly its industrialization, they marginalized the problem of economic autonomy of the countryside. One of the main adversaries of Grabski was Ludwik Krzywicki. He disparaged the rural-agricultural segment of Polish society as being at odds with "modern tendencies," primarily because of the ideology embedded in evolutionist thought. In addition, he did not hide his personal aversion to peasants, whom he called "thick-headed" and attached to the land. According to the trajectory of the unidirectional socio-economic development which he professed, they were bound to disappear from the horizon of the modern world. Allow me to digress here. The subject deserves special treatment and, in my personal view, it is hopefully not too late in the sense that the object of study - the countryside - might dissolve into oblivion unnoticed before our eyes. ${ }^{5}$ Let me, therefore, remind the reader that even in the first phase of the transformation, when there were no more illusions that the collapse of communism would be followed by a rapid transition towards the new system, I pointed out the dilemmas of rural society [Wieruszewska 1996]. I argued with the widespread belief that it was an "under-organized civil society." I pointed out that democracy cannot be treated as an end in itself, but as a method of defending civil rights and guaranteeing participation in public life. I argued that the countryside as a local community is an "indirect link" in which an individual is confronted with an institution of his or her society, and where, above all, it was on the basis of community [not associations] ties that the principles of social coexistence are formed. It follows that neither the territorial basis, nor the process of "fostering" institutions related to structures such as family, neighbourhood, church or nation for extended periods of time, could be an alternative method to build a civic culture. It must not be overlooked, however, that in sociologists' optics, it was specifically for the abovementioned reasons that the rural community did fit within the democratic vision as defined at that time. The shape of civil society organized according to the "model of primitive communities," "ethos groups" and denominations, to which individuals belonged with their "body and soul," was negated. These groups, forming an "autarkic

Although more than eighty years have passed since the debate between Władysław Grabski and Ludwik Krzywicki, the sociology of the countryside is still burdened by the wrong assumptions, which are duplicated as a model feature of rural communities. Among them, quite stereotypically, are listed such characteristics as isolationism (both physical and mental), traditionalism, or mythologizing the community. 
social experience," allegedly hindered the formation of unions and associations based on the principle of "aspect-based links with others" [Wieruszewska 1996]. I pointed out that different models of democracy were forgotten, and that civil society consists of groups capable of independent existence and defence, as emphasized by Piotr Gliński. The complexity, variability, and lack of clarity of the systemic transformation in which Polish society participated after 1989 cannot be an excuse for the narrative about the countryside and agriculture dominant at that time. In my opinion, sociological analyses did not fulfil their diagnostic and critical role. On the other hand, economic analyses steered clear (by a large margin) of the complex agro-rural problem, which did not fit into the existing models and established theories. One can agree with Barbara Fedyszak-Radziejowska's assertion that "the message of everything that shapes our community and identity" had become almost completely neglected.

\section{CONCLUSIONS}

The narrative style in this essay, which readers may perhaps find somewhat unusual, if not tedious, stems from my decision to make this my own commentary. It has been meant as a description of a scholarly culture close to my environment on account of my work. The drawbacks pointed out have not been dictated so much by a polemic passion for finding gaps, negligence, omissions or intentionally concealed threads. Above all, I wish to reveal the losses suffered by villages themselves as local communities within the same adoped time structures of the longue durée, which resulted in the amputation of achievements of countryside researchers from the Second Republic of Poland. The saying that sometimes one can see better from a distant perspective is thus proven to be true. In striving to overcome the "alienness" that divides the spheres of culture and economy, it is worth making the effort to challenge this division. Bearing in mind that successful societies have managed to reconcile the rules of democracy with market principles, such efforts are most advisable. In my opinion, however, the pejorative tone of the interpretation and description of the countryside should be rejected in general. Such a discursive discrimination, using the slogans of populism, parochialism, and backwardness without "making an attempt to look at them closely and assessing the ideas behind them" [Deejka 2016: 512] is not a good testament for sociology. On the other hand, the "rhetorical knock-out" argument of the economy aimed at small family farms, which are accused of failing to meet the commodity criteria and are unable to compete in the global market, shifts the sociological issues of the countryside away from the field of view. The façade of the market and pseudo- 
-democratic "newspeak" disguises the way in which the cultural values of the countryside as a viable potential for its revitalization are downplayed [Wieruszewska 1992: 158]. Researchers of today's farm management problems are aware of the constraints of economy insulated against the context of society and culture. Jacek Tittenbrun [Tittenbrun 2012] was one of the contemporary Polish researchers to examine the conjoining of economic mechanisms and social relations. The early attempts to reflect on the institutional basis of farm management have been noted [Wilkin 2016]. In general, the social, cultural, and therefore also moral anchor of economic processes is becoming more and more often noticed. It is no accident, therefore, that I, as an ethnographer, have taken up the subject "Culture - Economy. Space for Humanists" [Wieruszewska 2012]. The "close-to-life" approach, including economically, is now becoming a proof of the usefulness of ethnography for understanding the influence of culture on economic decisions.

\section{REFERENCES}

Bukraba-Rylska Izabella. 2008. Socjologia wsi polskiej. Warszawa: Wydawnictwo Naukowe PWN.

Dejneka Piotr. 2016. Populizm emancypacyjny a sfera publiczna czyli kilka słów o „dobrym populizmie" we współczesnej dyskusji politycznej w Polsce. Przypadek KOD-u w kontekście „widma populizmu krążącego po Europie. In: Przemiany kulturowe we wspótczesnej Polsce. Ramy, właściwości, epizody. J. Kurczewska, M. Karkowska (eds.), 511-533. Warszawa: Polska Akademia Nauk, Komitet Socjologii, Instytut Filozofii i Socjologii PAN.

Fedyszak-Radziejowska Barbara. 2017. "Polska wojna secesyjna. O głębokich źródłach i skutkach narodowej traumy z dr Barbarą Fedyszak-Radziejowską rozmawia Wiesława Lewandowska". Niedziela 27.07.2017: 38-39.

Filipkowski Piotr. 2016. Chłop polski w PRL-u (i potem) - doświadczenia, wartości, strategie. Analiza narracji biograficznych. In: Przemiany kulturowe we współczesnej Polsce. Ramy, właściwości, epizody. J. Kurczewska, M. Karkowska (eds.), 143-171. Warszawa: Polska Akademia Nauk, Komitet Socjologii, Instytut Filozofii i Socjologii PAN.

Gawkowska Aneta. 2004. Biorąc wspólnotę poważnie? Komunitarystyczne krytyki liberalizmu. Warszawa: Wydawnictwo Instytutu Filozofii i Socjologii Polskiej Akademii Nauk.

Gumula Wiesław. 2000. W poszukiwaniu początku zmian rynkowych w Polsce. In: Społeczna gospodarka rynkowa w Polsce. Model a rzeczywistość. S. Partycki (ed.), 113-123. Lublin: Wydawnictwo Uniwersytetu Marii Curie-Skłodowskiej

Kochanowicz Jacek. 2010. Wprowadzenie. In: Kultura i gospodarka. J. Kochanowicz, M. Marody (eds.), 1-20. Warszawa: Wydawnictwo Naukowe Scholar.

Kościański Artur. 2016. Partycypacja obywatelska a syndrom zmiany orientacji życiowych w społeczeństwie polskim. In: Przemiany kulturowe we współczesnej Polsce. Ramy, właściwości, epizody. J. Kurczewska, M. Karkowska (eds.), 233-250. 
Krzemiński Ireneusz, Jacek Raciborski. 2007. Wstęp. Socjologowie wobec wielkiej zmiany. In: Oswajanie wielkiej zmiany. Instytut Socjologii UW o polskiej transformacji. I. Krzemiński, J. Raciborski (eds.), 7-17. Warszawa: Wydawnictwo IFiS PAN.

Majcherek Janusz. 2016. „Modernizować modernizację”. Gazeta Wyborcza. 8.02.2016: 6.

Romaniszyn Krystyna. 2013. Rolnictwo w Mc Świecie. In: Nie tylko o wsi....Szkice humanistyczne dedykowane Profesor Marii Wieruszewskiej-Adamczyk. D. Kasprzyk (eds.), 61-88. Łódź: Wydział Filozoficzno-Historyczny Uniwersytetu Łódzkiego.

Swadźba Stanisław. 2000. Czy społeczna gospodarka rynkowa może być docelowym modelem polskiej gospodarki? (rozważania z punktu widzenia rozwoju europejskiej integracji). In: Społeczna gospodarka rynkowa w Polsce. Model a rzeczywistość. S. Partycki. (ed.), 499-506. Lublin: Wydawnictwo Uniwersytetu Marii Curie- Skłodowskiej.

Szczepański Jan. 1992. O roli indywidualności w życiu wsi i rozwoju rolnictwa. In: Odnowa wsi między mitem a nadzieją. M. Wieruszewska (ed.), 78-114. Warszawa: Polska Akademia Nauk.Instytut Rozwoju Wsi i Rolnictwa.

Sztompka Piotr. 2002. Socjologia. Analiza społeczeństwa. Kraków: Wydawnictwo Znak.

Tittenbrun Jacek. 2012. Gospodarka w społeczeństwie. Zarys socjologii gospodarki i socjologii ekonomicznej w ujęciu strukturalizmu socjoekonomicznego. Poznań: Wydawnictwo Zysk i S-ka

Tobiasz-Lis Paulina. 2015. Obraz wsi i rolnictwa w polskich i angielskich podręcznikach do geografii. In: Studia obszarów wiejskich t. 40. Edukacja i kapitał ludzki w rozwoju lokalnym i regionalnym, M .Wójcik, K. Czapiewski (eds.), 169-179. Warszawa: Komisja Obszarów wiejskich, Polskie Towarzystwo Geograficzne, Instytut Geografii Przestrzennego Zagospodarowania, Polska Akademia Nauk.

Wieruszewska Maria. 1991. Wieś. W poszukiwaniu całości społeczno-kulturowej. Warszawa: Polska Akademia Nauk, Instytut Rozwoju Wsi i Rolnictwa.

Wieruszewska Maria. (ed.). 1992. Odnowa wsi. Między mitem a nadzieją. Warszawa: Polska Akademia Nauk, Instytut Rozwoju Wsi i Rolnictwa.

Wieruszewska Maria. 1996. „Demokracja-partycypacja-elity. Dylematy społeczeństwa wiejskiego". Zagadnienia Naukoznawstwa 3(129): 293-301.

Wieruszewska Maria. 2000. Rodzinne gospodarstwo rolne a wybrane cechy społecznej gospodarki rynkowej. Zbieżna perspektywa teoretyczna. In: Społeczna gospodarka rynkowa w Polsce. Model a rzeczywistość. S. Partycki (ed.), 539-543. Lublin: Wydawnictwo Uniwersytetu Marii Curie-Skłodowskiej. Wydział Filozofii i Socjologii.

Wieruszewska Maria. 2008. „Tożsamość kulturowa wsi. Kwestie i zobowiązania”. Przegląd Humanistyczny 6: 31-45.

Wieruszewska Maria. 2011. Zarządzenie programem Leader z perspektywy kapitału społecznego. Założenia, działania, efekty - próba ewaluacji jakościowej. In: Między interwencja a interakcja. Lokalne grupy działania w społecznościach wiejskich. I. Bukraba-Rylska (ed.), 34-64. Warszawa: Wydawnictwo Naukowe Scholar.

Wieruszewska Maria. 2012. „Kultura - gospodarka. Przestrzeń dla humanistów”. Etnografia Polska LVI. 1-2: 143-155.

Wieruszewska Maria. 2014. „Myślenie o wsi i regionie w kategorii wspólnoty: anachronizm czy aktualna perspektywa?" Wieś i Rolnictwo 1(162): 139-153.

Wieruszewska Maria. 2016. „Wieś - miasto. Opozycje, antagonizmy, splątane narracje”. Zeszyty Wiejskie XXII: 53-67. Tom dedykowany Profesorowi Andrzejowi Lechowi. 
Wilkin Jerzy. 2016. Instytucjonalne i kulturowe podstawy gospodarowania. Humanistyczna perspektywa ekonomii. Warszawa: Wydawnictwo Naukowe Scholar.

Woś Jerzy. 2000. Społeczno-ekonomiczne aspekty adaptacji gospodarki rynkowej w warunkach polskich. In: Społeczna gospodarka rynkowa w Polsce. Model a rzeczywistość. S. Partycki (ed.), 569-575. Lublin: Wydawnictwo Uniwersytetu Marii Curie-Skłodowskiej. Wydział Filozofii i Socjologii.

Maria Wieruszewska

\section{GOSPODARKA - KULTURA. RAMA REFLEKSJI W DEBACIE O WSI}

Streszczenie

Esej ilustruje napięcia pomiędzy gospodarką rynkową i kulturą demokratyczną w odniesieniu do sytuacji polskich wsi stojących wobec wyzwań nowego systemu politycznego i gospodarczego po roku 1989. Autorka podkreśla ważną rolę założeń, które wynikają z teoretycznego zaplecza ekonomii i socjologii. Wskazuje na „ukrytą rolę”, jaką one pełnią w debacie dotyczącej szans przystosowania się wiejskich społeczności do wymagań nowoczesności. Autorka kwestionuje szeroko rozpowszechnioną w socjologii opinię o społeczności wiejskiej „niedostatecznie obywatelsko zorganizowanej" tylko jako efektu kolizji systemu wartości pomiędzy tradycyjnym lokalnym zasobem kulturowym wsi rolniczych a współczesnymi regułami rynku. Wskazuje, iż demokracja nie może być traktowana jako cel sam w sobie, ale powinna być traktowana jako metoda obrony praw obywatelskich i gwarancja uczestnictwa w życiu publicznym. Autorka uważa, że wsie [społeczności lokalne] tworzą „ogniwo pośrednie” w których jednostki stykają się z instytucjami swego społeczeństwa i w których zasady społecznego współżycia rozwijają się najpierw na podstawie więzi wspólnotowych. To prowadzi ją do konkluzji, że ani podstawa terytorialna [lokalna] ani proces „rośnięcia” lokalnych instytucji, powiązanych w długim horyzoncie czasu z takimi strukturami jak rodzina, sąsiedztwo, Kościół i naród, nie tworzą opozycji wobec kultury obywatelskiej. Historia dowodzi, że sukces osiagnęły te kraje, którym udało się pogodzić gospodarkę rynkową z zasadami demokratycznymi. Z drugiej strony obserwujemy, że im więcej gospodarki rynkowej tym mniej farm rodzinnych. Dla przetrwania rodzinnych gospodarstw rolnych, tym samym też dla odnowy kulturowej tradycji polskiej wsi słuszne wydaje się przełamanie „obcości rynku i kultury”. Rynek z przymiotnikiem „,społeczny” jest dlatego bardziej właściwy dla wprowadzenia w życie idei demokracji i spełnienia się oczekiwań zrównoważonego rozwoju [sustainable development] na polskiej wsi.

Słowa kluczowe: ekonomia, socjologia, kultura, demokracja, rozwój, wspólnota 